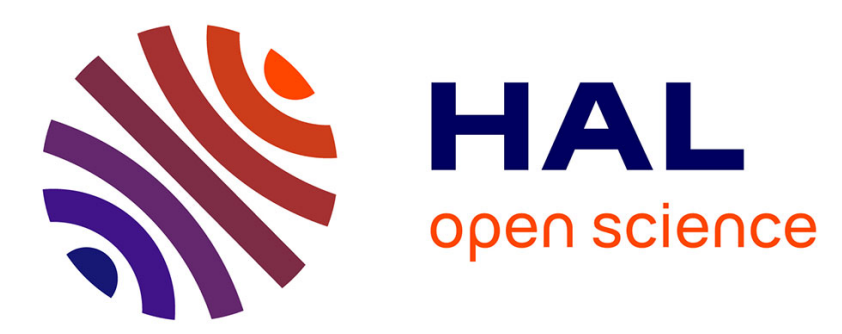

\title{
Exudates of different marine algae promote growth and mediate trace metal binding in
}

\author{
M. Teresa S.D. Vasconcelos, M. Fernanda C. Leal
}

\section{To cite this version:}

M. Teresa S.D. Vasconcelos, M. Fernanda C. Leal. Exudates of different marine algae promote growth and mediate trace metal binding in. Marine Environmental Research, 2008, 66 (5), pp.499. 10.1016/j.marenvres.2008.07.002 . hal-00501974

\section{HAL Id: hal-00501974 \\ https://hal.science/hal-00501974}

Submitted on 13 Jul 2010

HAL is a multi-disciplinary open access archive for the deposit and dissemination of scientific research documents, whether they are published or not. The documents may come from teaching and research institutions in France or abroad, or from public or private research centers.
L'archive ouverte pluridisciplinaire HAL, est destinée au dépôt et à la diffusion de documents scientifiques de niveau recherche, publiés ou non, émanant des établissements d'enseignement et de recherche français ou étrangers, des laboratoires publics ou privés. 


\section{Accepted Manuscript}

Exudates of different marine algae promote growth and mediate trace metal binding in Phaeodactylum tricornutum

M. Teresa S.D. Vasconcelos, M. Fernanda C. Leal

PII:

S0141-1136(08)00189-X

DOI:

10.1016/j.marenvres.2008.07.002

Reference:

MERE 3271

To appear in:

Marine Environmental Research

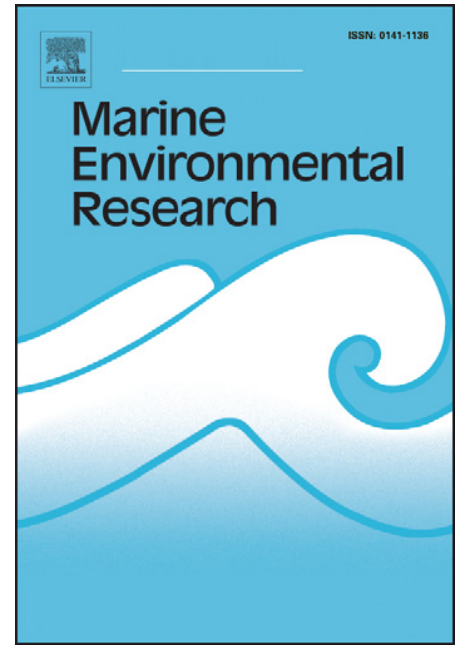

Received Date: $\quad 14$ August 2007

Revised Date: $\quad 11$ July 2008

Accepted Date: $\quad 15$ July 2008

Please cite this article as: Vasconcelos, M.T.S.D., Leal, M.F.C., Exudates of different marine algae promote growth and mediate trace metal binding in Phaeodactylum tricornutum, Marine Environmental Research (2008), doi: 10.1016/j.marenvres.2008.07.002

This is a PDF file of an unedited manuscript that has been accepted for publication. As a service to our customers we are providing this early version of the manuscript. The manuscript will undergo copyediting, typesetting, and review of the resulting proof before it is published in its final form. Please note that during the production process errors may be discovered which could affect the content, and all legal disclaimers that apply to the journal pertain. 
Exudates of different marine algae promote growth and mediate trace metal binding in Phaeodactylum tricornutum

M. Teresa S. D. Vasconcelos ${ }^{* a, b}$, M. Fernanda C. Leal ${ }^{\mathrm{a}, \mathrm{c}}$

${ }^{a}$ Departamento de Química, Faculdade de Ciências, Universidade do Porto, Rua do Campo Alegre 687, 4169-007 Porto, Portugal

${ }^{\mathrm{b}}$ Center of Marine and Environmental Research, CIIMAR, Rua dos Bragas 289, 4050-123 Porto,

Portugal

${ }^{\mathrm{c}}$ Present address: Faculty of Health Sciences, University Fernando Pessoa, Rua Carlos da Maia 296, 4200-150 Porto, Portugal

\footnotetext{
* Corresponding author. Fax: +351-22-6082959; E-mail address: mtvascon@fc.up.pt.
} 


\section{Abstract}

P. tricornutum was grown in filtered natural seawater enriched with nitrate, phosphate, and silicate only (control) or with exudates from itself, from Emiliania huxleyi (a coccolithophore micro-alga), Porphyra spp. (a red macro-alga) or Enteromorpha spp. (a green macro-alga). Cathodic (and anodic) stripping voltammetry $(\mathrm{C}(\mathrm{A}) \mathrm{SV})$ were used to determine the concentrations of trace metals, both in the medium and in the algae, as well as total $\mathrm{Cu}$-complexing organic ligands in the medium and, among these, some thiols (compounds identified as cysteine- or as glutathione by CSV). Exudates of different marine micro- and macro-algae could cause allelopathic effects in $P$. tricornutum cultures. Cell yield of $P$. tricornutum was increasingly promoted by exudates of $E$. huxleyi $>$ Porphyra $>$ Enteromorpha. Although exudates strongly complex $\mathrm{Cu}$ (and probably other metals), their presence promoted $\mathrm{Cu}$ uptake. Significant changes of $\mathrm{Ni}, \mathrm{Cd}, \mathrm{Fe}, \mathrm{Zn}$ and $\mathrm{Mn}$ uptake by $P$. tricornutum were also observed in the presence of exudates of different algal species. In addition, both intensity of production and nature of exudates released by $P$. tricornutum were markedly influenced by the presence of exudates of other algae, the allelopathic effects being very specific (variable from one species to another). Allelopathy will probably also occur in the aquatic environment, although to a lesser extent than in cultures, particularly during bloom events and may have effects on both chemical speciation and bioavailability of chemicals to phytoplanktonic species. Such changes might cause the predominance of some species over other species. Therefore, in future in vitro culture studies with the purpose of using them as models of the real environment, more attention should be paid to the role of algal exudates, in order to improve the environmental relevance and significance of the results.

Keywords: Allelopathy; Phaeodactylum tricornutum; Exudates; Organic ligands; Thiols; Trace metals 


\section{Introduction}

Any process involving secondary metabolites produced by plants, microorganisms, viruses and fungi that influences the growth and development of agricultural and biological systems excluding animals can be called allelopathy (Romeo, 2000). Although allelopathy has been mostly associated with inhibitory effects on growth, promotion of growth may also be classified as an allelopathic effect according to that broad definition. Data on allelopathy among algae are still very scarce. Sukenik et al. (2002) have observed that Microcystis sp. (cyanobacteria) severely inhibited the growth of Peridinium gatunense (dinoflagellate) in mixed laboratory cultures. Some effects caused by the presence of different species in the same culture have been observed and attributed to the excretion of substances with allelopathic properties. Micromonas pusilla growth was inhibited in the presence of Phaerodactylum tricornutum or Heterocapsa niei marine microalgae, compared to single-species tests (Franklin et al., 2004). In addition to algal exudate production, competition for nutrients, including $\mathrm{CO}_{2}$, may have accounted for those effects. Vasconcelos et al. (2002) have studied the influence of exudates from different algal species (micro- and macro-algae) on the behaviour of Emiliana huxleyi in seawater cultures. An improvement in the final cell yield of $E$. huxleyi was caused by the addition of Enteromorpha spp. (a green macro-alga) exudates, and growth inhibition (a decrease in final cell yield and growth rate) was observed in the presence of $P$. tricornutum (a diatom) exudates. Exudates of Enteromorpha were found to be rich in thiolic compounds which were identified by Cathodic Stripping Voltammetry (CSV) as being glutathione, and $P$. tricornutum exudates were rich in thiolic compounds which behaved in CSV like cysteine. $P$. tricornutum is an efficient producer of phytochelatins (peptides that contain glutamate, cysteine and glycine with the basic formula $(\gamma-\text { Glu-Cys })_{n}$-Gly with $\left.n=2-11\right)$, capable of readily synthesising a wide range of phytochelatins under metal stress (Rijstenbil and Wijnholds, 1996). It has also been observed that the nature and concentration of the organic compounds present in the culture medium 
conditioned trace metal sorption, as well as the concentration and composition of the exudates produced by E. huxleyi (Vasconcelos et al., 2002).

The aim of the present work was to study the behaviour of $P$. tricornutum cultures in the presence of exudates produced by themselves in a previous culture, or by E. huxleyi, Porphyra spp. (a red macro-alga) or Enteromorpha spp. Multispecies algal bioassays would be more realistic for allelopathic studies but interpretation of the results would be difficult. The study was carried out using natural coastal seawater enriched only with nitrate, phosphate, silicate and algal exudates. For the interpretation of results, concentrations of trace metals, total organic ligands, and thiol identified by CSV as cysteine and glutathione compounds were taken into consideration.

\section{Materials and Methods}

\subsection{Reagents}

The water used for reagent preparation and rinsing was deionised with conductivity $<0.1 \mu \mathrm{S}$ $\mathrm{cm}^{-1}$. The reagents and standards were prepared as before (Vasconcelos et al., 2002).

The natural seawater used in this study originated from the sea surface, $150 \mathrm{~m}$ from the coast at Póvoa do Varzim (Northwestern Portugal) and collected in October 2000. The seawater was pumped continuously from the ocean through a PVC pipe at a rate of $100 \mathrm{~L} \mathrm{~s}^{-1}$, and collected at the end of the discharge pipe directly to cleaned 25 L HDPE containers. In the laboratory, the seawater (35\%o salinity, $\mathrm{pH} 8.0)$ was immediately filtered ( $0.1 \mu \mathrm{m}$ polycarbonate membrane, Millipore) and stored in 50 L HDPE containers. Seawater was sub-sampled in $500 \mathrm{~mL}$ HDPE bottles, stored in the dark at $4{ }^{\circ} \mathrm{C}$ and used for experiments within 1 week.

\subsection{Cleaning of materials and culture media}

All materials used were acid cleaned and microwave-sterilised as described before (Leal et al. 1999). The culture media were sterilised by filtration $(0.1 \mu \mathrm{m}$ pore-size filter). All sample 
manipulations were carried out using gloves, in a Class 100 laminar flow hood in a clean room with HEPA filtered air. The absence of bacteria in the cultures was tested before and after experiments using standard bacteriological non-selective growth medium, and bacteria were not observed during the entire growth period. In addition, bacteria were not observed by using a microscope with an oil immersion lens.

\subsection{Attainment of seawater enriched with exudates}

Sterilised seawater was supplemented only with $176 \mu \mathrm{mol} \mathrm{L}^{-1}$ nitrate (from sodium nitrate, Merck), $7.26 \mu \mathrm{mol} \mathrm{L}{ }^{-1}$ phosphate (from sodium dihydrogenophosphate, Merck) and $21.4 \mu \mathrm{mol} \mathrm{L}{ }^{-1}$ silicate (from sodium silicate, Merck, used only in the case of $P$. tricornutum) and was inoculated (1 L polycarbonate bottle) with $1 \mathrm{ml}$ of an $\mathrm{f} / 2$ (Stein 1973) stock unialgal, axenic, E. huxleyi (Lohmann PCC N ${ }^{\circ} 92$ and 92d, isolated by Hay and Muller, Plymouth Marine Laboratory) or $P$. tricornutum (from the same origin) culture. The initial concentration of algae was approximately $1.5 \times 10^{6}$ cells $\mathrm{L}^{-1}$ (P. tricornutum) or $0.5 \times 10^{6}$ cells $\mathrm{L}^{-1}$ (E. huxleyi). Algal exudates were obtained by growing up the respective algae for $7 \mathrm{~d}$ at $18^{\circ} \mathrm{C}$ under $16 \mathrm{~h}$ light (and $8 \mathrm{~h}$ dark) (exponential phase).

Seawater enriched with Porphyra spp. or Enteromorpha spp. exudates was obtained by submerging a fresh sample of each macroalgae ( $20 \mathrm{~g}$ wet weight of algae per litre of sterilised seawater) in a polycarbonate bottle, for $24 \mathrm{~h}$ (time enough for the liberation of a significant amount of exudates but insufficient for the degradation of the macroalgae, Vasconcelos and Leal, 2001) at $18{ }^{\circ} \mathrm{C}$ under $16 \mathrm{~h}$ light (and $8 \mathrm{~h}$ dark). The intertidal benthic macroalgae were collected by hand from the surface of the beach rocks at low tide at Matosinhos beach (Northwestern Portugal). The algae were randomly placed in acid-cleaned plastic bags and transported to the laboratory in seawater collected from the beach. Upon arrival at the laboratory, the algae were washed twice with $3.5 \%(\mathrm{w} / \mathrm{v})$ sterilised $\mathrm{NaCl}$ (filtered through a $0.1 \mu \mathrm{m}$ pore-size filter and of concentration identical to that of the natural environment to avoid osmotic crash). 
In all cases, the algae were removed by filtration through $0.45 \mu \mathrm{m}$ cellulose nitrate Millipore filters, and rejected. The medium was characterised in terms of the concentration of total dissolved metals, total organic ligands and specific thiols which could be identified by CSV.

\subsection{P. tricornutum cultures}

All of the media enriched with exudates were supplemented with macronutrients as described above, sterilised, and used to grow up $P$. tricornutum for $10 \mathrm{~d}$ at $18{ }^{\circ} \mathrm{C}$ under $16 \mathrm{~h}$ light (and $8 \mathrm{~h}$ dark). For this purpose, cells from the $\mathrm{f} / 2$ medium (used for the stock cultures) were centrifuged (at $1500 \mathrm{rpm}$ ) and re-suspended in natural seawater, for elimination of EDTA and metals and then inoculated. Algae were also grown in sterilised natural seawater enriched only with the macronutrients (control media). The initial concentration $P$. tricornutum was approximately 1.5 x $10^{6}$ cells $\mathrm{L}^{-1}$.

Before and after experiments the cell numbers were counted (Stein, 1973) using a microscope (Nikon, Eclipse E400).

All experiments were carried out in triplicate.

\subsection{Chemical characterisation of the cultures}

The total dissolved concentrations of the different trace metals $\left([\mathrm{M}]_{\mathrm{d}}\right)$ were determined, by $\mathrm{CSV}$, in the culture media before and after algal growth, after removing the algae by filtration ( 0.45 $\mu \mathrm{m}$ pore-size filter) in a vacuum filtration system (Millipore) at 0.6 bar. Microscopic examination of the algae on the filter revealed that they did not suffer from rupture or breakage during filtration. Aliquots of the media were acidified to $\mathrm{pH} 2.2$ and were UV-digested (Ultramed 1000-W mercury vapour lamp, from Osram) in PTFE-capped quartz silica tubes for $1 \mathrm{~h}$. Acidification at a lower $\mathrm{pH}$ value $(\mathrm{pH}$ 1.5) and/or higher UV-irradiation time resulted in statistically identical results. Metal concentrations were determined by CSV, after neutralisation of the $\mathrm{pH}$ with $6 \mathrm{M}$ ammonia. The voltammetric equipment has been described before by Leal et al (1999). The determination of $\mathrm{Cu}$, 
$\mathrm{Pb}, \mathrm{Cd}, \mathrm{Zn}, \mathrm{Mn}$ and $\mathrm{Ni}$ was carried out by $\mathrm{CSV}$ at $\mathrm{pH} 8.3$ (0.01 $\mathrm{M}$ borate buffer) using, as the competitive ligand, $25 \mu \mathrm{M}$ salicylaldoxime for $\mathrm{Cu}$ (Campos and van den Berg, 1994), $0.01 \mathrm{mM}$ 8hydroxyquinoline for $\mathrm{Pb}$ and $\mathrm{Cd}$ (Colombo and van den Berg, 1997), $100 \mu \mathrm{M}$ ammonium pyrrolidinedithiocarbamate for Zn (van den Berg, 1985) and $0.2 \mathrm{mM}$ dimethylglyoxime for $\mathrm{Ni}$ (Colombo and van den Berg, 1997). The determination of Fe was carried out also by CSV at pH 6.9 (0.01 M PIPES buffer) using $0.4 \mathrm{mM}$ catechol as the competitive ligand (van den Berg and Huang, 1984). The determination of Mn was carried out by CSV at $\mathrm{pH} 8.3$ (0.01 M borate buffer) but without any added competitive ligand (Vasconcelos and Leal, 2001). Deposition step: $E_{d}(V)=-1.1$ $(\mathrm{Cu}),-1.0(\mathrm{~Pb}, \mathrm{Cd}),-1.3(\mathrm{Zn}),-0.1(\mathrm{Fe}),-1.7(\mathrm{Mn}),-0.8(\mathrm{Ni}) ; \mathrm{t}_{\mathrm{d}}(\mathrm{s})=60-120$. The scanning parameters were: frequency $(\mathrm{Hz}): 50(\mathrm{Cu}, \mathrm{Zn}), 200(\mathrm{~Pb}, \mathrm{Cd}, \mathrm{Mn}), 10(\mathrm{Fe}, \mathrm{Ni})$; modulation amplitude (mV): $25(\mathrm{Cu}, \mathrm{Pb}, \mathrm{Cd}, \mathrm{Mn}, \mathrm{Zn}), 50(\mathrm{Fe}, \mathrm{Ni})$; step potential $(\mathrm{mV}): 2.44(\mathrm{Cu}, \mathrm{Zn}), 3.66(\mathrm{~Pb}$, $\mathrm{Cd}, \mathrm{Fe}, \mathrm{Mn}, \mathrm{Ni}$ ); modulation time (s): 0.01 (Fe, Ni, Co); interval time (s): 0.1 (Fe, Ni, Co); squarewave $(\mathrm{Cu}, \mathrm{Pb}, \mathrm{Cd}, \mathrm{Zn}$ and $\mathrm{Mn})$, differential-pulse ( $\mathrm{Fe}$ and $\mathrm{Ni})$. In all cases a hanging mercury electrode (HMDE) was used. $[\mathrm{M}]_{\mathrm{d}}$ was also determined, using the same procedures, in a seawater reference material for trace metals (NASS-5) and the experimental values were found to not be statistically different from the certified values (' $\mathrm{t}$ ' test, $\mathrm{P}>0.05$ ).

The concentrations of the total $\mathrm{Cu}$-complexing organic ligands $\left(\mathrm{C}_{\mathrm{L}}\right)$ in the media and the respective conditional stability constants $\left(\mathrm{K}_{\mathrm{CuL}}^{\prime}\right)$ were determined by titration of the filtered culture media with $\mathrm{Cu}$ and measured by CSV with ligand competition (Campos and van den Berg, 1994; Leal et al., 1999). For CSV determinations, the $\mathrm{pH}$ was fixed at 8.3 (0.01 $\mathrm{M}$ borate) and salicylaldoxime ligand $(5 \mu \mathrm{M})$ was added to $120 \mathrm{ml}$ of sample solution. It was observed in a previous study (Leal and van den Berg, 1998) that during the CSV Cu complexing ligand titrations (added $\mathrm{Cu}$ concentration in the range $0-50 \mathrm{nM}$ ), the detected concentration of two synthetic organic ligands (cysteine and glutathione), and the conditional stability constants of their $\mathrm{Cu}$ complexes, did not vary significantly when the salicylaldoxime concentration was varied in the range $2-10 \mu \mathrm{M}$. Aliquots of $10 \mathrm{ml}$ of sample solution were pipetted into eleven polystyrene vials also containing 
added $\mathrm{Cu}$ in the range of $0-200 \mathrm{nM}$ (or other, if required), in approximately equal increments. The solutions were equilibrated overnight (12-15 h) prior to the determinations. The operationally labile $\mathrm{Cu}$ concentration $\left([\mathrm{Cu}]_{\text {labile }}\right.$ ) was determined as described for $[\mathrm{Cu}]_{\mathrm{d}}$, but without previous acidification and UV-digestion, using a $60 \mathrm{~s}$ adsorption step $\left(\mathrm{t}_{\mathrm{d}}\right)$ and deposition potential $\left(\mathrm{E}_{\mathrm{d}}\right)$ of -0.2 $\mathrm{V}$, whilst stirring. This $\mathrm{E}_{\mathrm{d}}$ was used rather than the more negative used for $[\mathrm{Cu}]_{\mathrm{d}}$, so as to prevent dissociation of the CuL complexes The scanning parameters were the same used in the $[\mathrm{Cu}]_{\mathrm{d}}$ determinations (described above).

Thiolic compounds were identified and quantified in the culture media using a method independent of that used for $\mathrm{C}_{\mathrm{L}}$ determinations (Al-Farawati and van den Berg, 1997; Leal et al., 1999). The determinations were carried out by CSV at $\mathrm{pH} 8.3$ (0.01 M borate buffer). Deposition step: $\mathrm{E}_{\mathrm{d}}=-0.25 \mathrm{~V}, \mathrm{t}_{\mathrm{d}}=60 \mathrm{~s}$. The scanning parameters were: scan rate, $20 \mathrm{mVs}^{-1}$; modulation amplitude, $25 \mathrm{mV}$; and square-wave frequency of $50 \mathrm{~Hz}$. The procedure was repeated after the addition of thiol standard (cysteine or glutathione) for calibration. The cysteine peak was located at $-0.47 \mathrm{~V}$ and the glutathione peak at $-0.58 \mathrm{~V}$.

Total metal concentrations in the algae $\left([\mathrm{M}]_{\text {algae }}\right)$ (extracellular adsorption plus intracellular uptake) were determined after microwave-digestion (Milestone MLS-1200 Mega) of the filters with $1 \mathrm{~mL}$ of suprapure, concentrated, nitric acid (from Merck) in high-pressure Teflon vessels and then were diluted with water and neutralised with ammonia. The metal concentrations were then determined as in the culture media. The metal fixed per microalgal cell $\left([\mathrm{M}]_{\text {cell }}\right)$ was calculated from the $[\mathrm{M}]_{\mathrm{algae}}$ and cell counts. Control filters were processed using the same procedure, but the metal contamination was found to be insignificant $(<1 \%)$. $[\mathrm{M}]_{\text {algae }}$ approximately balanced the metal lost from the seawater (with an error $<5 \%$ ), confirming that metal adsorption onto the polycarbonate culture bottles was negligible. Reference standard seaweed (CRM 279 Ulva lactuca) was used to check the accuracy of the digestion and analysis procedures. The metal contents found were not significantly different from expected values (' $t$ ' test, $\mathrm{P}>0.05$ ). 


\subsection{Multivariate analysis}

Influence of culture media composition on trace metal uptake by $P$. tricornutum was examined using principal components analysis (PCA) by means of PRIMER software (Clarke and Warwick, 1994; Clarke, 1999).

\section{Results and Discussion}

\subsection{Changes observed in the culture media of different algal species}

A complete characterization of the media in which micro- and macroalgae were incubated could not be performed due to technical limitations. However, levels of total organic ligands, $C_{L}$ (evaluated as being those capable of strong complexation with $\mathrm{Cu}(\mathrm{II})$ ), trace metals and cysteineand glutathione-like thiols were determined. Thiols may be very relevant components of these media. In fact, previous work carried out with similar culture media has shown that thiols (that is, compounds identified as being cysteine or glutathione in CSV, because the respective peak coincided with that of the thiol standard added for calibration) accounted with about $87 \%$ of the total dissolved organic ligands (Vasconcelos et al., 2002). In addition, statistically significant correlations between $\mathrm{C}_{\mathrm{L}}$ and thiols were recorded by Vasconcelos et al. (2002), suggesting that these thiolic compounds may be major contributors to the organic ligands released by eukaryotic algae. There is evidence that sulfur-containing compounds of low molecular mass are important components of the pool of ligands responsible for the nearly complete complexation of $\mathrm{Cu}$ in surface seawater. Free cysteine is known to occur in seawater (van den Berg et al., 1988). Compounds identified as glutathione ( $\gamma$ glutamylcysteinylglycine) have also been found in seawater (Le Gall and van den Berg, 1993) and estuarine waters (Tang et al., 2000; Laglera and van den Berg, 2003; Tang et al., 2004). Therefore, despite other compounds that may be released by the algae, the chemicals measured in the present work seems to be pertinent to the interpretation of the results. 
It was observed that either micro- or macro-algae enriched the seawater with organic ligands (L) and change the levels of trace metals (see day 0 of growth in Table 1). Cultures of $P$. tricornutum displayed higher concentrations of the determined exudates than E. Huxleyi did, despite the same numbers of cells in the inoculation. The macro-alga Enteromorpha also produced more exudates than Porphyra, although the initial algal mass was the same. The composition of the identified exudates varied with the alga species, although the overall conditional stability constants of the respective $\mathrm{Cu}$-complexes were similar in all media $\left(\log \mathrm{K}^{\prime}{ }_{\mathrm{Cu}(\mathrm{II}) \mathrm{L}}\right.$ between 12.07 and 12.65). Glutathione-like compounds were released in all media by the following increasing order: $P$. tricornutum $<$ E. huxleyi $<$ Porphyra $<$ Enteromorpha, whereas cysteine-like compounds were released only in media in which micro-organisms were incubated, the concentration being about 7 times higher for $P$. tricornutum culture. It should be noted that in the media enriched with $P$. tricornutum exudates the total concentration of $\mathrm{Cu}$-complexing organic ligands, $\mathrm{C}_{\mathrm{L}}$, was markedly lower than the sum of the concentrations of cysteine- and glutathione-like compounds. This result may account the fact of the $\mathrm{Cu}$ :thiol stoichiometric ratios can be either 1:2 (Leal and van den Berg, 1998) or 1:1 (Le Gall and van den Berg, 1993), depending on the metal to ligand concentration ratio in the medium.

Production and liberation of complexing substances by phytoplankton has frequently been related to the deficiency or excess of trace metal levels, in comparison to levels common in natural seawater. For instance, liberation of glutathione by the diatom T. weissflogi (Tang et al., 2004, 2005) or cysteine by E. huxleyi (Dupont et al., 2004; Dupont and Ahner, 2005) was found to increase in response to an increase of $\mathrm{Cu}$ in the medium. In response to a rise in $\mathrm{Cu}, \mathrm{Cd}$ or $\mathrm{Zn}$ concentrations, exudation of arginine-cysteine, glutamine-cysteine, cysteine, glutathione or $\gamma$ glutamate-cysteine by the coccolithophorid huxleyi have been recorded (Dupont and Ahner, 2005). On the other hand some compounds are released in response to a deficiency in micronutrients, as is the case with phytosiderophores released by plants in response to a deficiency in Fe or $\mathrm{Zn}$ (Reichard et al., 2005). In the present work the micro- and macro-algae were incubated in coastal 
natural seawater without addition of metals, therefore we can not infer if the trace metal levels available in the media condition the nature and concentration of exudates.

Incubation of the micro- and macro-algae for 7 days caused some changes in the trace metal contents of the respective media. Levels of $\mathrm{Pb}$ and $\mathrm{Fe}$ decreased slightly but significantly in all cultures, with greater reduction in $\mathrm{Pb}$ in the medium incubated with E. huxleyi, and $\mathrm{Fe}$ in the medium incubated with $P$. tricornutum. For Mn the more relevant change occurred in the medium containing Enteromorpha, which displayed a very marked increase of Mn levels. The levels of $\mathrm{Zn}$ decreased significant and markedly for E. huxleyi and P. tricornutum and to a lesser extent for Porphyra, but in contrast, increased considerably in the presence of Enteromorpha which released $\mathrm{Zn}$ into the medium. Therefore, Enteromorpha was the only alga that could release metals (Mn and $\mathrm{Zn}$ ) into the medium and did not remove any metal from the medium. This alga can bioaccumulate metal, being used as metal bioindicator (Say et al., 1986; Leal et al., 1997). This is compatible with its ability to liberate metals in seawater probably poorer in metals than that present at the site from which the alga were collected. Levels of $\mathrm{Cu}, \mathrm{Cd}$ and $\mathrm{Ni}$ did not change significantly in any media relative to the initial seawater composition.

\subsection{Comparison of growth, exudation and trace metal sorption of $P$. tricornutum in different media}

\subsubsection{Growth}

The cell yield of $P$. tricornutum attained a maximum after about $7 \mathrm{~d}$ incubation in most of the media (see Fig. 1). Similar growth profile curves for $P$. tricornutum in $f / 2$ medium were observed previously by Kudo et al. (1996).

Table 1 shows that all the media in which $P$. tricornutum was incubated promoted cell yield. In addition, all but the medium containing the exudates from $P$. tricornutum could promote slightly higher growth rate. These increased by the order $\left(\right.$ day $\left.^{-1}\right)$ : natural seawater $=$ with $P$. tricornutum exudates $(0.909)<$ with E. huxleyi exudates $(0.971)<$ with Porphyra exudates $(1.17)<$ with 
Enteromorpha exudates (1.28). These are only indicative values as the statistical mean of rates is questionable because the calculation was based on only 2-3 points. However, the cell yield followed the same order, and it was identical for E. huxleyi and Porphyra exudates. The P. tricornutum yield in natural seawater was similar to that observed before (Kudo et al., 1996) in similar experimental conditions. Promotion of $P$. tricornutum growth in the media in which different algae had been incubated was as follows: (a) lower or higher levels (depending on the medium) of some metals relative to those present in the natural water (Table 1) did not limit growth or were toxic to $P$. tricornutum; (b) the presence of exudates of the micro- or macro-algae control metal toxicity and direct or indirectly promoted the $P$. tricornutum growth.

Exudates of E. huxleyi slightly promoted growth of $P$. tricornutum (Table 1 ) whereas in a previous study, in which $E$. huxleyi has been incubated in seawater enriched in exudates of $P$. tricornutum and with similar trace metal levels, a drastic inhibition of E. huxleyi growth was observed (Vasconcelos et al., 2002). These contrasting results indicate that the nature and effects of chemicals released by eukaryotic algae can vary markedly among species. P. tricornutum grows well in the presence of E. huxleyi exudates, but E. huxleyi is inhibited by P. tricornutum, therefore the simultaneous presence of both algae in a natural site may lead to the disappearance of $E$. huxleyi, thus reducing biodiversity.

\subsubsection{Trace metal contents}

Table 1 also presents the initial total dissolved metal concentrations, $[\mathrm{M}]_{\mathrm{d}}$, and the concentrations after $7 \mathrm{~d}$ growth in all tested culture media, as well as the percentage of each metal that was transferred to the cells (surface adsorption and uptake). As the cell yields were not identical in the different cultures, the metal fixed per cell, $[\mathrm{M}]_{\text {cell }}$, was included in Table 1 . Note that the total metal content measured in the cells was statistically identical to the difference between the initial and final $[\mathrm{M}]_{\mathrm{d}}$ measured in the culture medium. 
Table 1 shows that $\mathrm{Cu}$ fixed per cell was similar or even higher in the presence of higher concentrations of exudates that are strong $\mathrm{Cu}$ ligands, indicating that algal exudates did not reduce the bioavailability of $\mathrm{Cu}$, on the contrary exudates promoted uptake in some cases. The more accentuated effect occurred in the culture with Enteromorpha exudates, where $[\mathrm{Cu}]_{\text {cell }}$ was $60 \%$ higher than in the control culture. This was in spite of the initial $[\mathrm{Cu}]_{\mathrm{d}}$ which was $20 \%$ lower (i.e. there was less $\mathrm{Cu}$ available per cell) and the final number of cells was $74 \%$ higher, causing much higher competition for the available $\mathrm{Cu}$. These results indicated that the algal exudates directly (e.g. forming lipophilic organic complexes) or indirectly (by unknown mechanisms) promoted the fixation of $\mathrm{Cu}$ (and other metals, see below) to P. tricornutum. Concomitantly, in the culture with Enteromorpha exudates there was also uptake of organic ligands (L), particularly glutathione-like compounds. These results are consistent with those previously reported multispecies algal bioassays for assessing $\mathrm{Cu}$ toxicity, involving three marine microalgae (Micromonas pusilla, P. tricornutum, and Heterocapsa niei) (Franklin et al., 2004). Cu toxicity to P. tricornutum was reduced, compared to single-species bioassays, and such reduction could not be explained by differences in the $\mathrm{Cu}$ complexing capacity in solution (as a result of exudates production) because labile $\mathrm{Cu}$, measured by anodic stripping voltammetry, has been similar for P. tricornutum alone and in the mixture.

In addition, in the presence of Enteromorpha exudates the amount of $\mathrm{Ni}$ fixed per cell, $[\mathrm{Ni}]_{\mathrm{cell}}$, was double that fixed in the presence of Porphyra exudates $\left(4.0 \times 10^{-18} \mathrm{vs.} 2.0 \times 10^{-18} \mathrm{~mol}\right.$ cell $^{-1}$ ), even though the initial $[\mathrm{Ni}]_{\mathrm{d}}$ was similar in both media and the final cells number was $30 \%$ lower in the last case, resulting in more $[\mathrm{Ni}]_{\mathrm{d}}$ available per cell. Higher cellular metal levels in the presence of Enteromorpha exudates were also found for Cd. Together, these results indicated that Enteromorpha exudates promoted the fixation of $\mathrm{Cu}, \mathrm{Cd}$ and $\mathrm{Ni}$ in P. tricornutum. The simultaneous uptake of glutathione like compounds, $66 \%$ of the initial values, seems to be implicated in higher metal sorption.

Remarkable results were also observed for $[\mathrm{Zn}]_{\text {cell }}$ and $[\mathrm{Mn}]_{\text {cell }}$ in the presence of Enteromorpha exudates, where $[\mathrm{Zn}]_{\mathrm{cell}}$ was only $41 \times 10^{-18} \mathrm{~mol} \mathrm{cell}^{-1}$, much lower than that in the 
control culture, $109 \times 10^{-18} \mathrm{~mol} \mathrm{cell}^{-1}$, despite the initial $[\mathrm{Zn}]_{\mathrm{d}}$ was more than two times higher in the culture enriched with Enteromorpha exudates (139 nmol L-1 vs. $59 \mathrm{nmol} \mathrm{L}^{-1}$ in the control). The lower $[\mathrm{Zn}]_{\text {cell }}$ was not caused by scarcity of dissolved $\mathrm{Zn}$ since the final $[\mathrm{Zn}]_{\mathrm{d}}$ was double of the initial $[\mathrm{Zn}]_{\mathrm{d}}$ in the control medium. The presence of relatively high levels of glutathione-like compounds may prevent Zn sorption. Gnassia-Barelli and Romeo (1987) found that Zn toxicity has been alleviated by the addition of algal exudates (aged cultures). Stauber and Florence (1990) found that most of the zinc associated with the cells of the marine diatom Nitzschia closterium were bound at the cell surface with only 3 to $4 \%$ of this extracellular zinc penetrating the cell membrane. In contrast to the $\mathrm{Zn}$ results, $[\mathrm{Mn}]_{\text {cell }}$ was much higher in the presence of Enteromorpha exudates (54 x $\left.10^{-18} \mathrm{~mol} \mathrm{cell}^{-1}\right)$, where the initial $[\mathrm{Mn}]_{\mathrm{d}}$ was also higher $\left(75 \mathrm{nmol} \mathrm{L}^{-1}\right)$ (in the control culture $[\mathrm{Mn}]_{\mathrm{cell}}=4.1 \times 10^{-18} \mathrm{~mol} \mathrm{cell}{ }^{-1}$ and the initial $[\mathrm{Mn}]_{\mathrm{d}}$ was only $\left.6.6 \mathrm{nmol} \mathrm{L}{ }^{-1}\right)$. Therefore, in the presence of relatively high levels of both $\mathrm{Zn}$ and $\mathrm{Mn}$ (and Enteromorpha exudates) the cells of $P$. tricornutum sorbed preferentially $\mathrm{Mn}$. This is compatible with the hypothesis that $\mathrm{Mn}$ could replace $\mathrm{Zn}$ in some cellular functions. A relationship between $\mathrm{Mn}$ and $\mathrm{Zn}$ has also been observed for other algae. For example, Sunda and Huntsman (1998) observed that up to $150 \mathrm{nmol} \mathrm{L}{ }^{-1}[\mathrm{Zn}]_{\mathrm{d}}$ inhibited cellular Mn uptake by the coastal alga Chlamydomonas sp. Nevertheless, this result contrasts with that observed in the present work. However, the previous work was carried out in absence of algal exudates and the culture medium contained a chelator (NTA or EDTA) as a trace metal buffer. Therefore, the composition of the culture medium (and the algal species) was very different from those used in the present work.

Other important findings were as follows. The exudates of all tested algae caused inhibition of Fe transfer to the P. tricornutum cells. For instance, in the presence of Porphyra exudates, the $[\mathrm{Fe}]_{\text {cell }}$ was $77 \%$ lower than that in the control culture, though the initial $[\mathrm{Fe}]_{\mathrm{d}}$ was only $11 \%$ lower, and the cell numbers only $35 \%$ higher. It must be noted that the final $[\mathrm{Fe}]_{\mathrm{d}}$ was much higher in the medium with Porphyra exudates than in the control $\left(14.3\right.$ vs. $\left.5.4 \mathrm{nmol} \mathrm{L}^{-1}\right)$ indicating that the lower $[\mathrm{Fe}]_{\text {cell }}$ was not caused by scarcity of Fe in the medium. Although Fe is considered the most 
important trace metal for plant metabolism, because Fe is required for many proteins, enzymes and reactions (Kudo et al., 2000), the lowest level of Fe per cell was observed in the culture which displayed the highest yield (and rate of growth). Possibly uptake of other elements could compensate for the decrease of cellular Fe.

To obtain a broader view of the influence of medium composition on P. tricornutum behaviour, PCA analysis based on trace metal uptake was carried out. Calculations were performed either for percentage of metal removed from the initial solution (\% uptake in Table 1$)$ or for metal taken up per cell, and results are plotted in Fig. 2a and $2 \mathrm{~b}$ respectively. For comparison, the influence of similar culture media on E. huxleyi behaviour observed before (Vasconcelos et al., 2002) was also analysed (Fig. 2 c and 2 d). For $P$. tricornutum cultures, the first two principal axes retained $80.5 \%$ (Fig. $2 \mathrm{a}$ ) or $85.8 \%$ (Fig. 2 b) of the variance from the initial seven dimensions. In Fig. 2a the first principal component (PC1) clearly separated the control and the medium with $P$. tricornutum exudates (grouped) from the medium with Enteromorpha exudates. This separation is based on a decreasing gradient of $\mathrm{Zn}$ and $\mathrm{Fe}$, and an increasing gradient of $\mathrm{Cu}$ and $\mathrm{Mn}$, as stated by the eigenvectors. The second principal component (PC2) separated the medium with E. huxleyi exudates from the other media, and is based on a decreasing gradient of $\mathrm{Pb}, \mathrm{Cd}$ and $\mathrm{Ni}$, as stated by the eigenvectors. Fig. 2b also indicates that control, Enteromorpha and E. huxleyi exudates media caused very distinct metal sorption, although in this case the medium with $P$. tricornutum exudates was grouped with the medium with Porphyra exudates.

For E. huxleyi cultures, higher differences occurred between P. tricornutum exudates and control grouped with exudates of its own alga (PC1, Fig. 2c, where the first two principal axes retained $84.3 \%$ of the variance from the original seven dimensions); PC2 separates the group formed by Enteromorpha and Porphyra exudates from the other media. Fig. 2d, where the first two principal axes retained $93.6 \%$ of the variance from the original seven dimensions, shows that $P$. tricornutum exudates caused metal uptake profiles very different from the other media. 
Therefore, independent of the units used in the estimation of metal sorption, PCA analysis confirmed that Enteromorpha exudates medium, in addition to promoting growth of P. tricornutum cells more than the remaining media, caused a very specific profile of metal sorption which did not depend only on the total dissolved metal concentration in the media. PCA revealed that profiles of metal sorption in the presence of E. huxleyi exudates were also very different than those for all the other media.

Enteromorpha and Porphyra exudates acted similarly to E. huxleyi alga, causing metal sorption profiles distinct from the other media, but the most marked uptake profile occurred in the presence of $P$. tricornutum exudates, which could inhibit E. huxleyi growth (Vasconcelos et al., 2002).

\subsubsection{Release and/or uptake of organic ligands in the different media}

The values of total final concentrations of organic ligands $\left(\mathrm{C}_{\mathrm{L}}\right)$ released or taken up per cell of P. tricornutum in the different media are shown in Fig. 3 a (see total $\mathrm{C}_{\mathrm{L}}$ in the solutions in Table $1)$.

The maximum production of organic ligands per cell of $P$. tricornutum occurred in the control medium. Therefore, exudates of all tested algal species inhibited the release of organic ligands by $P$. tricornutum, suggesting that exudates are released either to control excessive levels of some chemicals, like trace metals, or to promote uptake of nutrients. In addition, in the presence of Porphyra or Enteromorpha exudates, about $50 \%$ of the organic ligands initially present in the media were taken up by P. tricornutum cells (in the free form or bound to trace metal ions) during the 7 days of growth. These results were in contrast to those previously observed in cultures of $E$. Huxleyi (Vasconcelos et al., 2002), apart from the control media (Fig. 3b). In fact, in the media enriched with exudates of different algal species E. huxleyi liberated more exudates than in the natural seawater. In addition, in the presence of the exudates of $P$. tricornutum the amount of exudates released by E. huxleyi was about five times higher than that liberated into the other media. 
This result has been interpreted as a defence mechanism against toxicity induced, direct or indirectly, by the P. tricornutum exudates, which inhibited the growth of E. huxleyi. Therefore, the presence in the medium of exudates of certain algal species can affect the extent of exudation of other algae species in a very specific way. This may happen even when accentuated changes in the algal growth yield (stimulation or inhibition) are not detected, as was the case for the present $P$. tricornutum cultures in the present work.

The concentrations of the combined thiol compounds quantified in the different cultures were directly related to that of the total $\mathrm{Cu}$ ligand concentration present in the media (Table 1): $[\text { Thiols }]_{t}=(1.06 \pm 0.07) C_{L}-(12 \pm 9), R^{2}=0.84$. The similar magnitude and the covariation of the total organic ligand and total thiol concentrations suggests that these thiols may be major contributors to the organic $\mathrm{Cu}$ binding ligands released by $P$. tricornutum and other eukaryotic algae. In the present case, the measured thiols account for about $94 \%$ of the total $\mathrm{Cu}$ organic ligands. Similar results were found in a previous study with E. huxleyi (Vasconcelos et al., 2002) and confirms the importance of thiols as complexing agents in the tested cultures, and probably in natural systems where the producer algae are abundant.

Fig. 4a shows that cysteine-like compounds are released by P. tricornutum in all tested media (see also Table 1). The highest production during the growth (from $3.5 \mathrm{nmol} \mathrm{L}^{-1}$ to $92 \mathrm{nmol}$ $\mathrm{L}^{-1}$ ) occurred in the natural seawater (control medium) and the lowest in the medium enriched with P. tricornutum exudates (from $92 \mathrm{nmol} \mathrm{L}^{-1}$ to $106 \mathrm{nmol} \mathrm{L}^{-1}$ ). Apparently, the already relatively high initial concentration of cysteine-like compounds inhibited the release of these thiols by $P$. tricornutum.

In contrast, the concentration of glutathione-like compounds decreased by $\sim 50 \%$ during the growth of $P$. tricornutum in all media apart from the control (Fig. 4a), where the concentration of glutathione-like compounds was initially $22 \mathrm{nmol} \mathrm{L}^{-1}$ and increased by $\sim 50 \%$ after $7 \mathrm{~d}$ (Table 1). In the cultures enriched with Porphyra and Enteromorpha exudates the initial glutathione-like compounds were relatively high $\left(>100 \mathrm{nmol} \mathrm{L}^{-1}\right)$. Therefore, glutathione removal was high in the 
media with high initial concentration of glutathione, which varied as follows: natural seawater < with $P$. tricornutum exudates $<$ with E. huxleyi exudates $<$ with Porphyra exudates $<$ with Enteromorpha exudates. These thiolic compounds were probably taken up by the cells (see below), which is consistent with the decrease of the total organic ligand concentration in the media, as discussed above. The uptake of the thiolic compounds may be directly or indirectly implicated in the improvement of P. tricornutum cells yield observed in the presence of Porphyra and Enteromorpha exudates.

To ensure that the decrease of thiolic compounds in the media was a result of uptake by the organisms and not caused by degradation, in a previous study by Vasconcelos et al. (2002) $P$. tricornutum exudates, $150 \mathrm{nmol} \mathrm{L}^{-1}$ cysteine and $100 \mathrm{nmol} \mathrm{L}^{-1}$ glutathione were added, separately, to sterilised seawater which was conditioned like the algal cultures for 10 days. It was observed that the thiol concentrations were kept constant over the $10 \mathrm{~d}$ period, indicating that the decrease in the present study was really due to uptake by the micro-organisms. In addition, synthetic cysteine and glutathione were added to E. huxleyi cultures, causing changes in the growth similar to those induced by the $P$. tricornutum exudates (Vasconcelos et al., 2002). These results support the interpretation of the data concerning cysteine- and glutathione-like compounds in the present work.

A comparison of P. tricornutum organic ligand concentrations with those observed before for E. huxleyi in similar experimental conditions (Vasconcelos et al., 2002) (Fig. 4b) demonstrates that nature and intensity of cell exudation is markedly dependent on the algal species. Contrasting results are demonstrated by the effects of $P$. tricornutum exudates on E. huxleyi cell behaviour (growth inhibition) and the effects of E. huxleyi exudates in the P. tricornutum cell behaviour (growth promotion). Release or uptake of ligands may be related to metal uptake although how and to what extent can not be inferred from the available data..

Ahner et al. (2002) exposed five species of marine algae to variable concentrations of Cd and $\mathrm{Cu}$ and measured the intracellular concentrations of glutathione, cysteine, $\gamma$ glu-cys and phytochelatin. These authors found that glutathione in E. huxleyi seemed to decrease at high $\mathrm{Cu}$ 
concentrations, while in $P$. tricornutum it showed an increase at $\left[\mathrm{Cu}^{2+}\right]_{\text {free }}=1 \mathrm{nmol} \mathrm{L}^{-1}$. These results are compatible with those obtained in the present study: $P$. tricornutum took up an appreciable fraction of the glutathione-like compounds initially present in the media, whereas $E$. huxleyi released these thiols into all media. Very high rates of glutathione efflux have been invoked to explain the rapid increase in dissolved ligand concentrations in E. huxleyi cultures (Ahner et al., 2002). In addition, in response to Cd exposure both cysteine and $\gamma$ glu-cys (precursors to glutathione) increased in the presence of E. huxleyi, whereas only $\gamma$ glu-cys increased in the presence of $P$. tricornutum. Kawakami et al. (2006) have examined the effects of $\mathrm{Cu}, \mathrm{Cd}$ and $\mathrm{Zn}$ on the intracellular production of the polypeptides phytochelatin and glutathione by $P$. tricornutum. Single additions of $\mathrm{Cu}\left(0.4 \mu \mathrm{mol} \mathrm{L}{ }^{-1} \mathrm{Cu}^{2+}\right)$ and $\mathrm{Cd}\left(0.45 \mu \mathrm{mol} \mathrm{L} \mathrm{Cd}^{2+}\right)$ to the culture medium induced the production of phytochelatins, whereas a single addition of $\mathrm{Zn}\left(2.2 \mu \mathrm{mol} \mathrm{L} \mathrm{Zn}^{-1}\right)$ did not stimulate phytochelatin production. Combination of $\mathrm{Zn}$ and $\mathrm{Cu}$ resulted in a similar phytochelatin production as compared with a single $\mathrm{Cu}$ addition. The simultaneous exposure to $\mathrm{Zn}$ and $\mathrm{Cd}$ led to an antagonistic effect on phytochelatin production. Glutathione concentrations were affected only upon exposure to $\mathrm{Cd}$ (85 \% increase) or the combination of $\mathrm{Cd}$ with $\mathrm{Zn}$ (65\% decrease), relative to the control experiment. In some of the cited papers, the production of thiols occurred as a defence mechanism against exposure to relatively high trace metal levels, which was not the case in this work. The present results may be classified as allelopathic effects between algal species, and may take place in multispecies algal cultures or in the real environment, particularly during bloom events. Such phenomena can lead to predominance of some algal species and inhibition of other species. Simultaneously, important changes in chemical speciation of the media and metal uptake by phytoplankton may take place in the aquatic medium.

\section{Conclusion}


This work demonstrated that exudates of different marine micro- and macro-algae caused allelopathic effects in P. tricornutum cultures. Cell yield of $P$. tricornutum was increasingly promoted by exudates of E. huxleyi $>$ Porphyra $>$ Enteromorpha. Although exudates can strongly complex $\mathrm{Cu}$ (and probably other metals), their presence promoted $\mathrm{Cu}$ uptake. Significant changes of $\mathrm{Ni}, \mathrm{Cd}, \mathrm{Fe}, \mathrm{Zn}$ and Mn uptake by $P$. tricornutum were also observed in the presence of exudates of different algal species. In addition, both intensity of production and nature of exudates released by P. tricornutum were markedly influenced by the presence of exudates of other algae, the allelopathic effects being very specific (variable from one species to another).

The fact that $P$. tricornutum growth was promoted by macro-algae exudates which usually compete with this diatom (a basically benthic, rock pool species) may not to be entirely realistic. The present results were obtained in the absence of the exudates producers (living macro-algae), and it is possible that in a real aquatic system where the diatom and macro-algae exist together, other exudates with inhibitor properties will also be released by the macro-algae. Nevertheless, it is important to stress the fact of exudates of Porphyra and Enteromorpha (which can live together) gave rise to a markedly different response from the diatom, showing specific behaviour.

Although, allelopathy will occur in the aquatic environment, it will probably be to a lesser extent than in cultures, and primarily during bloom events and may have effects on both chemical speciation and bioavailability of chemicals to phytoplanktonic species. Such changes might cause the dominance of some species over other species. Therefore, in future studies involving in vitro cultures more attention should be paid to the role of algal exudates, in order to improve the significance of the results with the aim of using them as models of the real environment,

\section{Acknowledgements}

The Post-Doctoral grant of M. Fernanda C. Leal (PRAXIS XXI / BPD / 22095 / 99) was funded by the Portuguese Foundation for Science and Technology (FCT). Mr. Manuel Isidro from the Aquaculture of Rio Alto, Póvoa do Varzim, is acknowledged for providing facilities for collection of seawater. 


\section{References}

Al-Farawati, R., and van den Berg, C.M.G., 1997. The determination of sulfide in seawater by flowanalysis with voltammetric detection. Mar. Chem. 57, 277-286.

Ahner, B.A., Liping, W., Oleson, J.R., and Ogura, N., 2002. Glutathione and other low molecular weight thiols in marine phytoplankton under metal stress. Mar. Ecol. Prog. Ser. 232, 93-103.

Campos, M.L.A.M., and van den Berg, C.M.G., 1994. Determination of copper complexation in sea water by cathodic stripping voltammetry and ligand competition with salicylaldoxime. Anal. Chim. Acta 284, 481-496.

Clarke, K.R. and Warwick, R.M. 1994. Change in Marine Communities: An Approach to Statistical Analysis and Interpretation. Natural Environment Research Council, Plymouth, UK, 144.

Clarke, K.R. 1999. Non-metric multivariate analysis in community-level ecotoxicology. Environ. Toxicol. Chem. 18, 118-127.

Colombo, C., and van den Berg, C.M.G., 1997. Simultaneous determination of several trace metals in seawater using cathodic stripping voltammetry with mixed ligands. Anal. Chim. Acta 337, $29-40$.

Dupont, C.L., Nelson, R.K., Bashir, S., Moffett, J.W., and Ahner, A., 2004. Novel copper-binding and nitrogen-rich thiols produced and exuded by Emiliania huxleyi. Limnol. Oceanogr. 49, 1754-1762.

Dupont, C.L., and Ahner, B.A., 2005. Effects of copper, cadmium, and zinc on the production and exudation of thiols by Emiliania huxleyi. Limnol. Oceanogr. 50, 508-515.

Franklin, N.M., Stauber, J.L. and Lim, R.P., 2004. Development of multispecies algal bioassays using flow cytometry. Environ. Toxicol. Chem. 23, 1452-1462.

Gnassia-Barelli, M., and Roméo, M., 1987. Uptake of zinc by cultured phytoplankters Hymenomonas elongate. Dis. Aquat. Org. 3, 45-49. 
Kawakami, S.K., Gledhill, M., and Achterberg, E.P., 2006. Effects of metal combinations on the production of phytochelatins and glutathione by the marine diatom Phaeodactylum tricornutum. BioMetals. 19, 51-60.

Kudo, I., Kokubun, H., and Matsunaga, K., 1996. Chemical fractionation of phosphorus and cadmium in the marine diatom Phaeodactylum tricornutum. Mar. Chem. 52, 221-231.

Kudo, I., Miyamoto, M., Noiri, Y., and Maita, Y., 2000. Combined effects of temperature and iron on the growth and physiology of the marine diatom Phaeodactylum tricornutum (Bacillariophyceae). J. Phycol. 36, 1096-1102.

Laglera, L.M., and van den Berg, C.M.G., 2003. Copper complexation by thiol compounds in estuarine waters. Mar. Chem. 82, 71-89.

Leal, M.F.C., Vasconcelos, M.T.S.D., Sousa-Pinto, I., and Cabral, J.P.S., 1997. Biomonitoring with Benthic Macroalgae and Direct Assay of Heavy Metals in Seawater of the Oporto Coast. Mar. Poll. Bull. 34, 1006-1015.

Leal, M.F.C., and van den Berg, C.M.G., 1998. Evidence for Strong Copper(I) Complexation by Organic Ligands in Seawater. Aquatic Geochem. 4, 49-75.

Leal, M.F.C., Vasconcelos, M.T.S.D., and van den Berg, C.M.G., 1999. Copper Induced Release of Complexing Ligands Similar to Thiols by Emiliania huxleyi in Seawater Cultures. Limnol. Oceanogr. 44, 1750-1762.

Le Gall, A., and van den Berg, C.M.G., 1993. Cathodic Stripping Voltammetry of Glutathione in Natural Waters. Analyst 118, 1411-1415.

Reichard, P.U., Kraemer, S.M., Frazier, S.W., and Kretzschmar, R., 2005. Goethite Dissolution in the Presence of Phytosiderophores: Rates, Mechanisms, and the Synergistic Effect of Oxalate. Plant and Soil. 276, 115-132.

Rijstenbil, J.W, and Wijnholds, J.A., 1996. HPLC analysis of nonprotein thiols in planktonic diatoms: Pool size, redox state and response to copper and cadmium exposure. Mar. Biol. 127, 45-54. 
Romeo, J.T., 2000. Raising the beam: Moving beyond phytotoxicity. J. Chem. Ecol. 26, 2011-2014.

Say, P.J., Burrows, I.G., and Whiton, B.A., 1986. Enteromorpha as a Monitor of Heavy Metals in Estuarine and Coastal Intertidal Waters. Northern Environmental Consultants Ltd, Occasional Publication $n^{\circ} .1$, Durham.

Stauber, J.L., and Florence, T.M., 1990. Mechanism of toxicity of zinc to the marine diatom Nitzschia closterium. Mar. Biol., 105, 519-524.

Stein, J.R., 1973. Culture Methods and Growth Measurements, Isolation and Purification (Section I). Handbook of Phycological Methods. University Press, Cambridge.

Sunda, W.G., and Huntsman, S.A., 1998. Interactions among $\mathrm{Cu}^{2+}, \mathrm{Zn}^{2+}$, and $\mathrm{Mn}^{2+}$ in controlling cellular Mn, Zn, and growth rate in the coastal alga Chlamydomonas. Limnol. Oceanogr. 43, 1055-1064.

Sukenik, A., Eshkol, R., Livne, A., Hadas, O., Rom, M., Tchernov, D., Vardi, A., and Kaplan, A., 2002. Inhibition of growth and photosynthesis of the dinoflagellate Peridinium gatunense by Microcystis sp. (cyanobacteria): A novel allelopathic mechanism. Limnol. Oceanogr. 47, 1656-1663.

Tang, D., Hung, C., Warnken, K.W., and Santschi, P.H., 2000. The distribution of biogenic thiols in surface waters of Galveston Bay. Limnol. Oceanogr. 45, 1289-1297.

Tang, D.G., Shafer, M.M., Karner, D.A., Overdier, J., and Armstrong, D.E., 2004. Factors affecting the presence of dissolved glutathione in estuarine waters. Environ. Sci. Technol. 38, 42474253.

Tang, D., Shafer, M.M., Karner, D.A., and Armstrong, D.E., 2005. Response of nonprotein thiols to copper stress and extracellular release of glutathione in the diatom Thalassiosira weissfligii. Limnol. Oceanogr. 50, 516-525.

van den Berg, C.M.G., 1985. Determination of the zinc complexing capacity in seawater by cathodic stripping voltammetry of zinc-APDC complex ions. Mar. Chem. 16, 121-130. 
van den Berg, C.M.G., and Huang, Z.Q., 1984. Determination of iron in seawater using cathodic stripping voltammetry preceded by adsorptive collection with the hanging mercury drop electrode. J. Electroanal. Chem. 177, 269-280.

van den Berg, C.M.G., Househam, B.C., and Riley, J.P., 1988. Determination of cystine and cysteine in seawater using Cathodic Stripping Voltammetry in the presence of $\mathrm{Cu}(\mathrm{I})$. J. Electroanal. Chem. 239, 137-148.

Vasconcelos, M.T.S.D., and Leal, M.F.C., 2001. Seasonal variability in the kinetics of $\mathrm{Cu}, \mathrm{Pb}, \mathrm{Cd}$ and $\mathrm{Hg}$ accumulation by macroalgae. Mar. Chem. 74, 65-85.

Vasconcelos, M.T.S.D., Leal, M.F.C., and van den Berg, C.M.G., 2002. Influence of the nature of the exudates released by different marine algae on the growth, trace metal uptake and exudation of Emiliania huxleyi in natural seawater. Mar. Chem. 77, 187-210. 
Table 1. Trace metal $\left([\mathrm{M}]_{\mathrm{d}}\right)$, Cu-complexing ligands $\left(\mathrm{C}_{\mathrm{L}}\right)$ and thiol ([Cysteine] and [Glutathione]) contents ${ }^{\mathrm{a}}\left(\mathrm{nmol} \mathrm{L}^{-1}\right)$ in natural seawater, media in which micro- and macro-algae have been incubated and in the $P$. tricornutum cultures ${ }^{\mathrm{b}}$ in media enriched with exudates of different algal species. The numbers of cells at the end of the experiments are also given.

\begin{tabular}{|c|c|c|c|c|c|c|c|c|c|c|c|}
\hline Medium: Seawater & & $\mathrm{Cu}$ & $\mathbf{P b}$ & Cd & Zn & Fe & Mn & $\mathbf{N i}$ & $\mathrm{C}_{\mathrm{L}}^{\mathrm{c}}$ & Cysteine $^{d}$ & Glutathione $^{\mathrm{d}}$ \\
\hline Natural (control) & 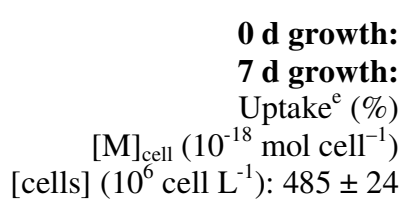 & $\begin{array}{c}6.8 \pm 0.2 \\
5.3 \pm 0.3 \\
22 \\
3.1 \pm 0.1\end{array}$ & $\begin{array}{c}0.36 \pm 0.02 \\
0.20 \pm 0.04 \\
44 \\
0.33 \pm 0.02\end{array}$ & $\begin{array}{c}0.19 \pm 0.01 \\
0.12 \pm 0.01 \\
37 \\
0.14 \pm 0.02\end{array}$ & $\begin{array}{c}59 \pm 2 \\
6.3 \pm 0.3 \\
89 \\
109 \pm 5\end{array}$ & $\begin{array}{c}20.5 \pm 0.4 \\
5.4 \pm 0.4 \\
74 \\
31 \pm 2\end{array}$ & $\begin{array}{c}6.6 \pm 0.7 \\
4.6 \pm 0.3 \\
30 \\
4.1 \pm 0.1\end{array}$ & $\begin{array}{c}6.7 \pm 0.2 \\
4.0 \pm 0.1 \\
40 \\
5.6 \pm 0.5\end{array}$ & $\begin{array}{c}48 \pm 3 \\
106 \pm 3\end{array}$ & $\begin{array}{c}3.5 \pm 0.2 \\
92 \pm 4\end{array}$ & $\begin{array}{l}22 \pm 1 \\
34 \pm 2\end{array}$ \\
\hline $\begin{array}{c}\text { Enriched with exu } \\
\text { E. huxleyi }\end{array}$ & $\begin{array}{l}\text { ites of: } \\
\text { 0 d growth: } \\
7 \text { d growth: } \\
\operatorname{Uptake}^{\mathrm{e}}(\%) \\
{[\mathrm{M}]_{\text {cell }}\left(10^{-18} \operatorname{mol~cell~}^{-1}\right)} \\
\text { [cells] }\left(10^{6} \text { cell L }^{-1}\right): 665 \pm 33\end{array}$ & $\begin{array}{c}5.2 \pm 0.3 \\
2.9 \pm 0.3 \\
44 \\
3.4 \pm 0.4\end{array}$ & $\begin{array}{c}0.13 \pm 0.01 \\
0.11 \pm 0.01 \\
15 \\
0.030 \pm 0.005\end{array}$ & $\begin{array}{c}0.10 \pm 0.02 \\
0.086 \pm 0.004 \\
14 \\
0.021 \pm 0.006\end{array}$ & $\begin{array}{c}7.8 \pm 0.4 \\
4.8 \pm 0.2 \\
38 \\
4.5 \pm 0.5\end{array}$ & $\begin{array}{c}15 \pm 1 \\
11 \pm 1 \\
27 \\
6.0 \pm 0.4\end{array}$ & $\begin{array}{c}5.2 \pm 0.4 \\
3.9 \pm 0.1 \\
25 \\
2.0 \pm 0.2\end{array}$ & $\begin{array}{c}4.7 \pm 0.2 \\
3.8 \pm 0.3 \\
19 \\
1.4 \pm 0.3\end{array}$ & $\begin{array}{c}74 \pm 2 \\
103 \pm 6\end{array}$ & $\begin{array}{c}12.0 \pm 0.6 \\
61 \pm 3\end{array}$ & $\begin{array}{l}61 \pm 3 \\
27 \pm 4\end{array}$ \\
\hline P. tricornutum & $\begin{array}{r}\text { 0 d growth: } \\
7 \text { d growth: } \\
\operatorname{Uptake}^{\mathrm{e}}(\%) \\
{[\mathrm{M}]_{\text {cell }}\left(10^{-18} \operatorname{mol~cell~}^{-1}\right)} \\
{[\text { cells }]\left(10^{6} \text { cell L }^{-1}\right): 540 \pm 27}\end{array}$ & $\begin{array}{c}5.1 \pm 0.2 \\
3.1 \pm 0.1 \\
39 \\
3.7 \pm 0.3\end{array}$ & $\begin{array}{c}0.20 \pm 0.02 \\
0.099 \pm 0.008 \\
50 \\
0.19 \pm 0.02\end{array}$ & $\begin{array}{c}0.14 \pm 0.03 \\
0.097 \pm 0.005 \\
31 \\
0.080 \pm 0.005\end{array}$ & $\begin{array}{c}5.1 \pm 0.4 \\
1.4 \pm 0.2 \\
72 \\
6.8 \pm 0.3\end{array}$ & $\begin{array}{c}5.6 \pm 0.8 \\
1.6 \pm 0.2 \\
71 \\
7.4 \pm 0.5\end{array}$ & $\begin{array}{c}4.8 \pm 0.2 \\
3.9 \pm 0.3 \\
19 \\
1.7 \pm 0.3\end{array}$ & $\begin{array}{c}4.6 \pm 0.5 \\
2.5 \pm 0.2 \\
46 \\
3.9 \pm 0.2\end{array}$ & $\begin{array}{l}106 \pm 3 \\
122 \pm 5\end{array}$ & $\begin{array}{c}92 \pm 4 \\
106 \pm 5\end{array}$ & $\begin{array}{c}34 \pm 2 \\
18.2 \pm 0.9\end{array}$ \\
\hline Porphyra & $\begin{array}{r}\text { 0 d growth: } \\
7 \text { d growth: } \\
\operatorname{Uptake}^{\mathrm{e}}(\%) \\
{[\mathrm{M}]_{\text {cell }}\left(10^{-18} \text { mol cell }^{-1}\right)} \\
\text { [cells] }\left(10^{6} \text { cell L }^{-1}\right): 653 \pm 33\end{array}$ & $\begin{array}{c}6.3 \pm 0.3 \\
4.4 \pm 0.2 \\
30 \\
2.9 \pm 0.2\end{array}$ & $\begin{array}{c}0.29 \pm 0.03 \\
0.11 \pm 0.01 \\
62 \\
0.28 \pm 0.01\end{array}$ & $\begin{array}{c}0.18 \pm 0.01 \\
0.14 \pm 0.02 \\
22 \\
0.060 \pm 0.002\end{array}$ & $\begin{array}{c}25 \pm 2 \\
13.6 \pm 0.5 \\
46 \\
17 \pm 2\end{array}$ & $\begin{array}{c}19.0 \pm 0.5 \\
14.3 \pm 0.4 \\
26 \\
7.2 \pm 0.6\end{array}$ & $\begin{array}{c}6.1 \pm 0.3 \\
1.8 \pm 0.3 \\
70 \\
6.6 \pm 0.5\end{array}$ & $\begin{array}{c}5.1 \pm 0.2 \\
3.8 \pm 0.1 \\
25 \\
2.0 \pm 0.4\end{array}$ & $\begin{array}{c}116 \pm 3 \\
77 \pm 2\end{array}$ & $13.1 \pm 0.5$ & $\begin{array}{c}110 \pm 6 \\
39 \pm 2\end{array}$ \\
\hline Enteromorpha & $\begin{array}{r}\text { 0 d growth: } \\
7 \text { d growth: } \\
\operatorname{Uptake}^{\mathrm{e}}(\%) \\
{[\mathrm{M}]_{\text {cell }}\left(10^{-18} \text { mol cell }^{-1}\right)} \\
\text { cells }]\left(10^{6} \text { cell } \mathrm{L}^{-1}\right): 845 \pm 42\end{array}$ & $\begin{array}{c}5.4 \pm 0.2 \\
1.2 \pm 0.2 \\
78 \\
5.0 \pm 0.4\end{array}$ & $\begin{array}{c}0.24 \pm 0.03 \\
0.13 \pm 0.01 \\
46 \\
0.13 \pm 0.02\end{array}$ & $\begin{array}{c}0.16 \pm 0.02 \\
0.052 \pm 0.005 \\
68 \\
0.13 \pm 0.01\end{array}$ & $\begin{array}{c}139 \pm 5 \\
104 \pm 2 \\
25 \\
41 \pm 3\end{array}$ & $\begin{array}{c}14.4 \pm 0.8 \\
10.3 \pm 0.3 \\
28 \\
4.8 \pm 0.2\end{array}$ & $\begin{array}{c}75 \pm 4 \\
29 \pm 2 \\
61 \\
54 \pm 3\end{array}$ & $\begin{array}{c}5.9 \pm 0.2 \\
2.5 \pm 0.2 \\
58 \\
4.0 \pm 0.2\end{array}$ & $\begin{array}{l}175 \pm 4 \\
123 \pm 5\end{array}$ & $\begin{array}{c}3.3 \pm 0.2 \\
23 \pm 1\end{array}$ & $\begin{array}{c}154 \pm 8 \\
88 \pm 4\end{array}$ \\
\hline
\end{tabular}

a- Mean values \pm standard deviation $(\mathrm{n}=3)$.

b- The initial $P$. tricornutum cells concentration was about $1.5 \times 10^{6}$ cell L-1.

c- Units: equivalents of $n m o l \mathrm{~L}^{-1} \mathrm{Cu}$.

a- Species determined by CSV as cysteine or glutathione.

e- Percentage of the initially soluble metal that was bound up with the cells (extra- and intra-cellularly). 


\section{Figure captions}

Fig. 1. Phaeodactylum tricornutum growth in the different culture media. Standard deviations $(\mathrm{n}=3)$ are also given.

Fig. 2. Principal component analysis plots for seven metals $(\mathrm{Cu}, \mathrm{Pb}, \mathrm{Cd}, \mathrm{Zn}, \mathrm{Fe}, \mathrm{Mn}$ and $\mathrm{Ni})$ and five culture media: natural seawater and seawater containing exudates from Enteromorpha, Porphyra, Emiliania huxleyi and Phaeodactylum tricornutum algae. (a) \% Metal uptake by $P$. tricornutum; (b) Metal uptake per cell of P. tricornutum; (c) \% Metal uptake by E. huxleyi; (d) Metal uptake per cell of E. huxleyi.

Fig. 3. Cu-complexing ligand concentrations released (or taken up) by Phaeodactylum tricornutum after $7 \mathrm{~d}$ growth in media enriched with exudates from different algae (a). Results are compared with those obtained before in similar conditions in Emiliania huxleyi cultures (Vasconcelos et al., 2002) (b). Standard deviations ( $\mathrm{n}=3$ ) are also given.

Fig. 4. Comparison of thiol compounds released (or taken up) by Phaeodactylum tricornutum after 7 d growth (a). Results obtained before for Emiliania huxleyi (Vasconcelos et al., 2002), in similar media, are included for comparison (b). Standard deviations $(n=3)$ are also given. 


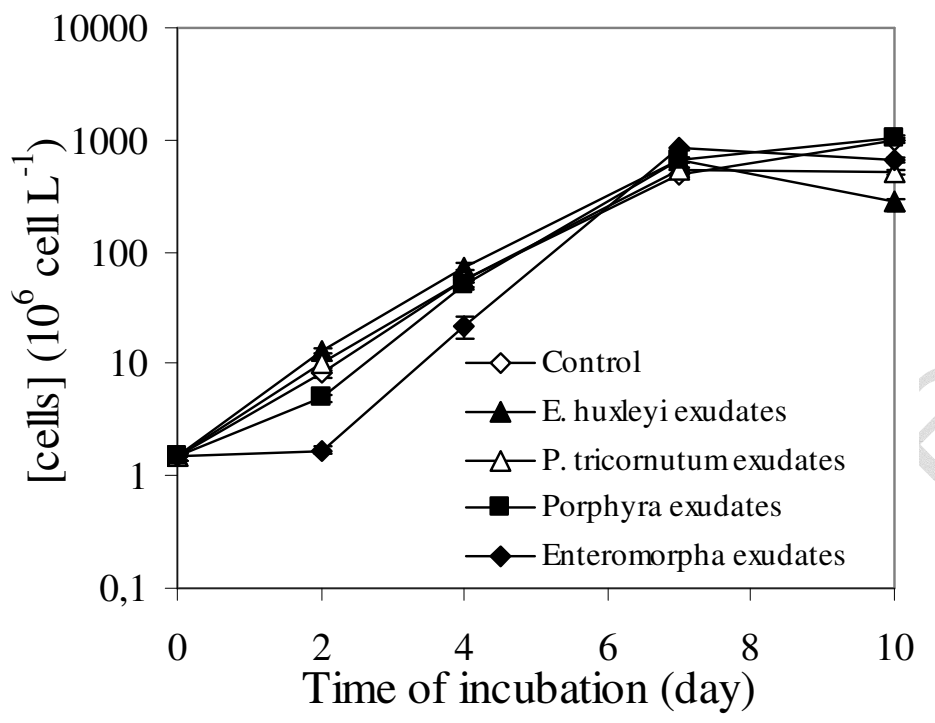

Fig. 1 


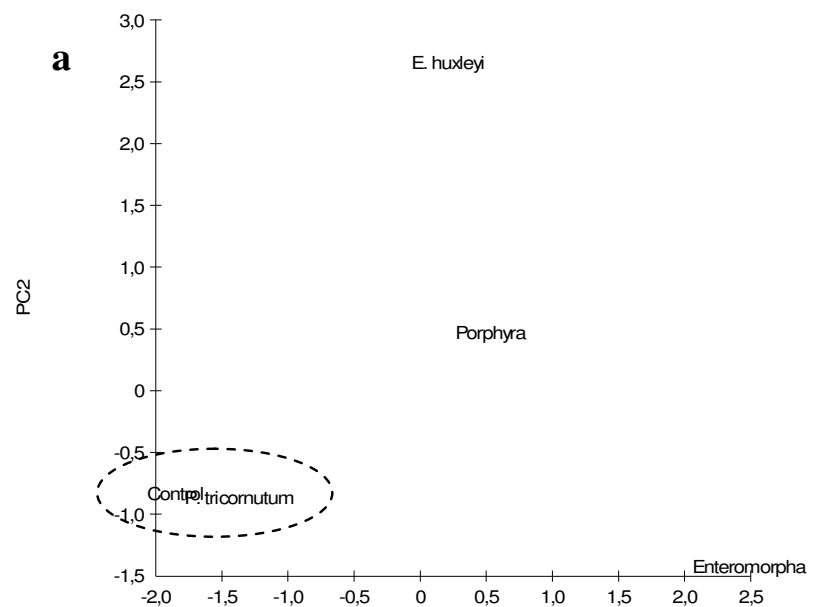

PC1

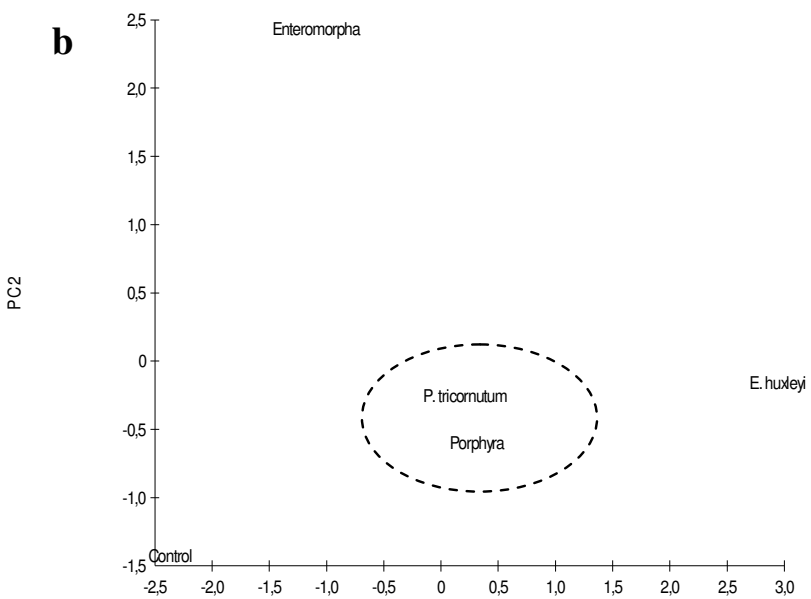

PC1

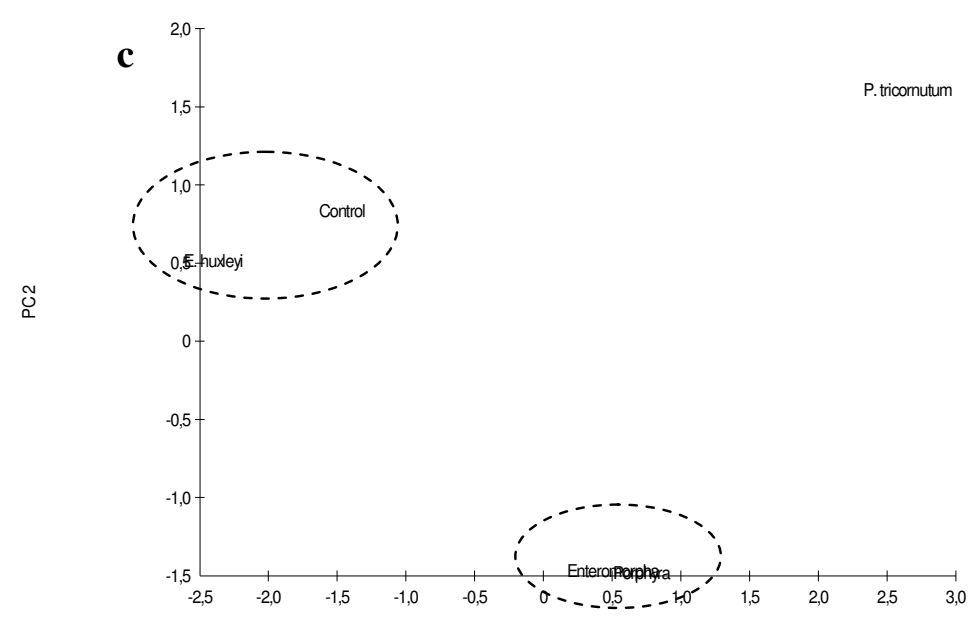

PC

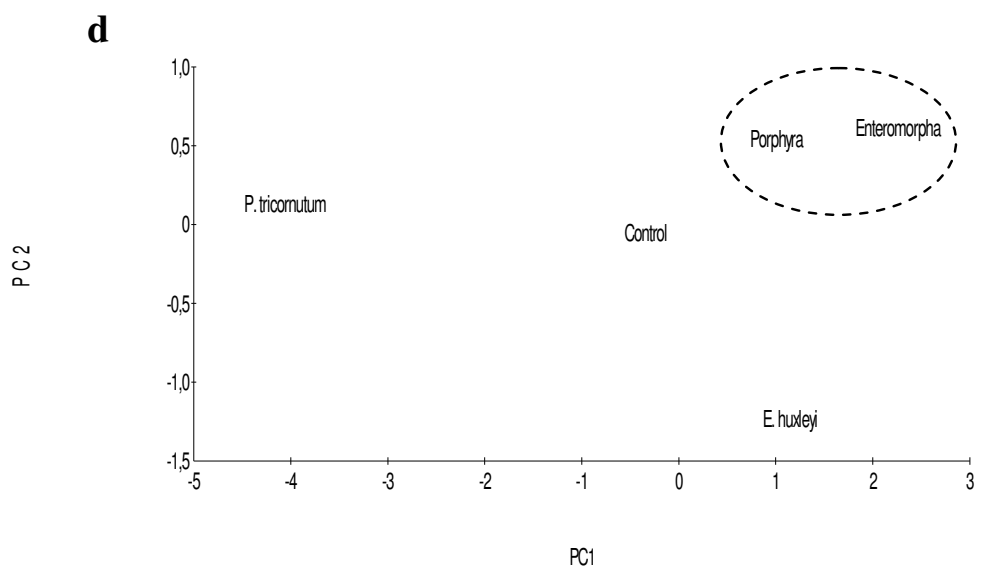

Fig. 2 


\section{P. tricornutum cultures}
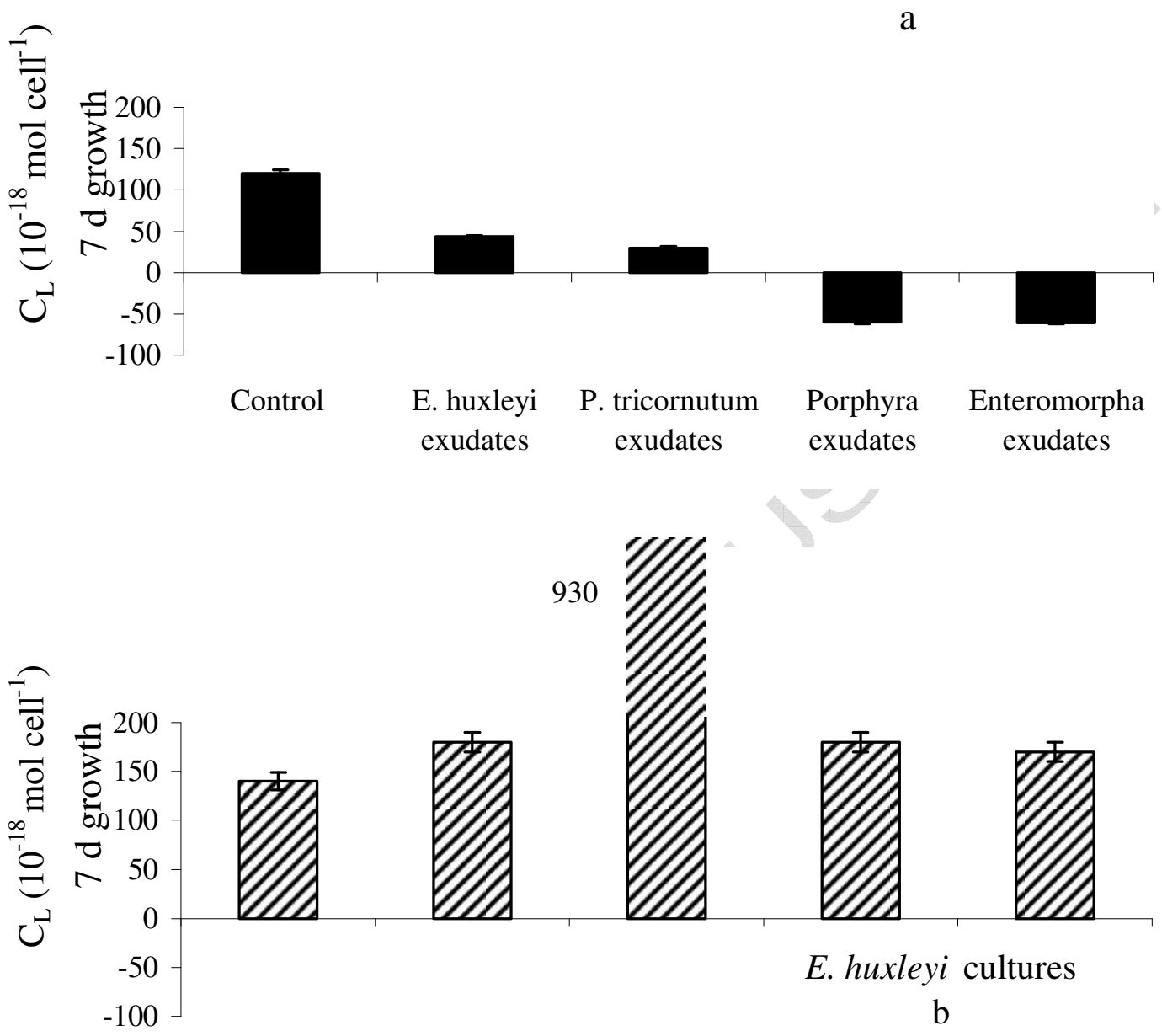

Fig. 3 


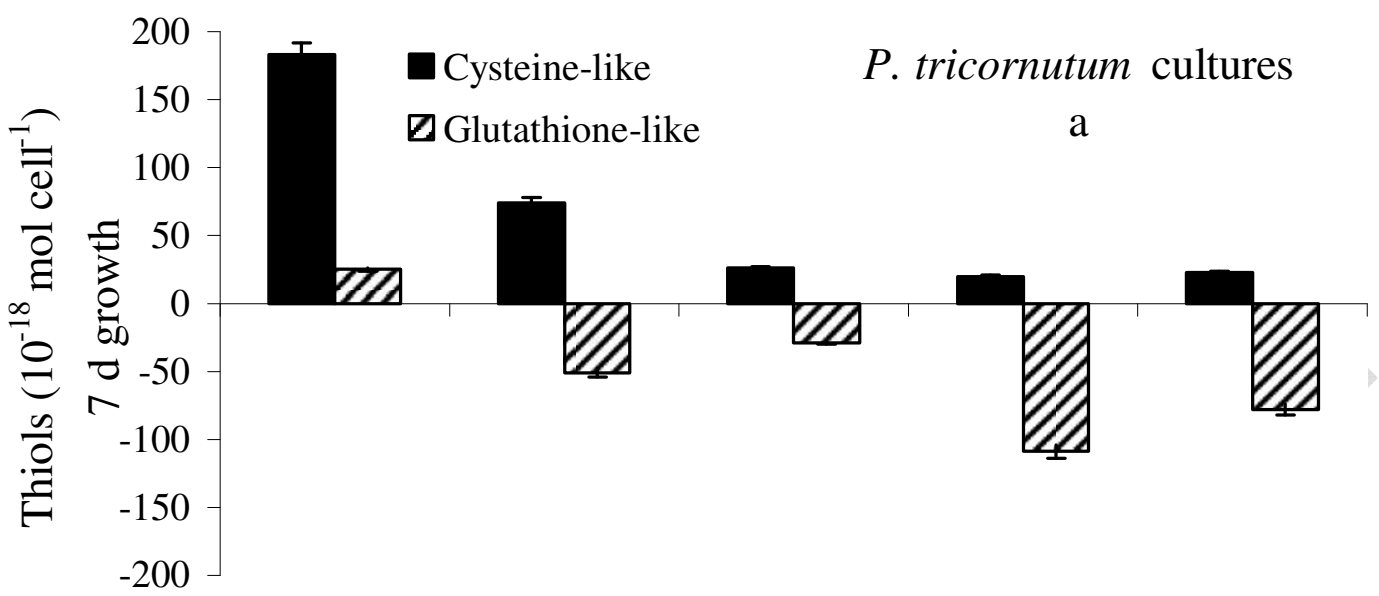

Control

P.

tricornutum

exudates
Enteromorpha

exudates

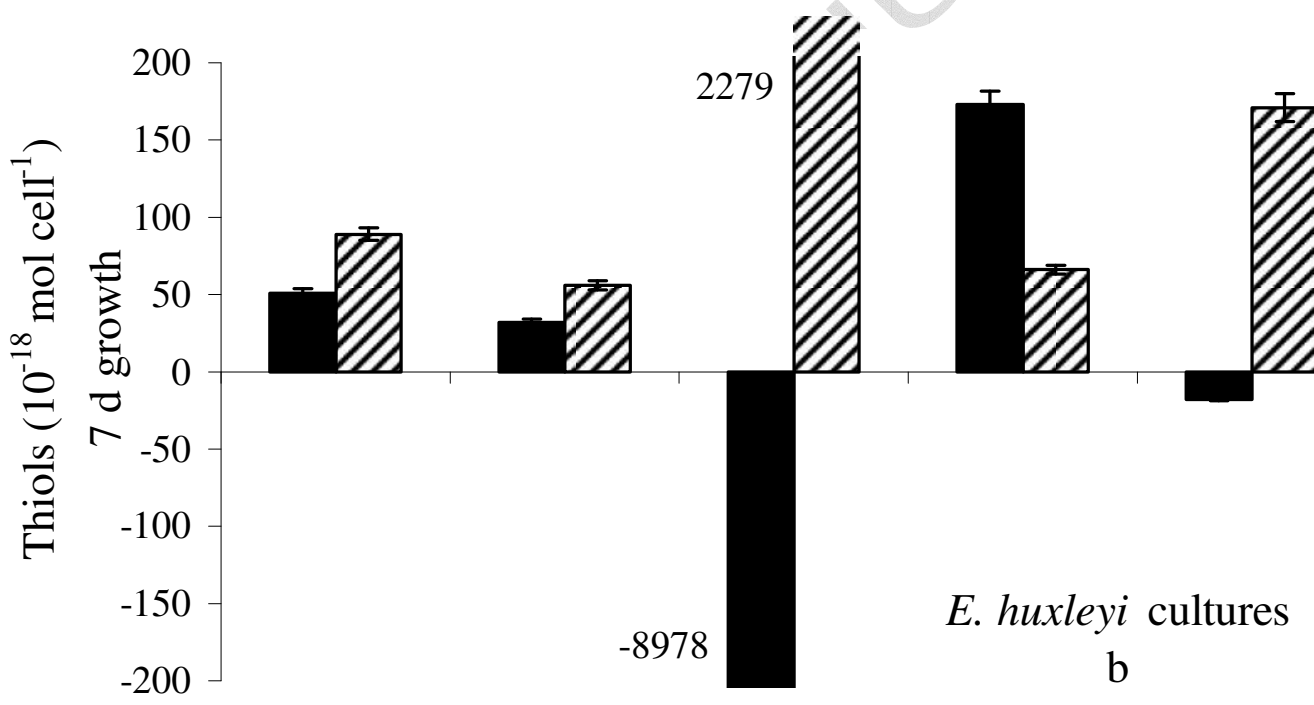

Fig. 4 